\title{
Judicial Resistance to Copyright Law's Inalienable Right to Terminate Transfers
}

\author{
Peter S. Menell* and David Nimmer**
}

For a century, Congress has sought to protect authors and their families by allowing them to grant their copyrights for exploitation and then, decades later, recapture those same rights. After judicial interpretation of the 1909 Act frustrated this intent, Congress spoke unambiguously in 1976: "Termination of the grant may be effected notwithstanding any agreement to the contrary ...."1 Yet the Second Circuit in Penguin (USA) v. Steinbeck has eviscerated that clear Congressional command by enabling a grantee to renegotiate the terms of the grant so as to frustrate recapture by the author's family. ${ }^{2}$ Notwithstanding the unequivocal meaning of the word "any" in $\S 304(c)(5)$, explicated unmistakably in the legislative history, the decision invites grantees to engage in all manner of opportunistic behavior to frustrate Congress' clearly expressed language and intent.

\section{STATUTORY BACKGROUND OF COPYRIGHT RECAPTURE}

Prior to the 1976 Act, an author's future interest in his work was the right to renew copyright for a second term. In theory, the right of renewal gave authors and their families a second chance to benefit from the work by canceling unremunerative transfers and regaining copyright. Yet authors rarely got what Congress had originally intended, as publishers routinely required authors and their families to assign renewal rights in advance. Because Congress concluded that alienable reversionary interests did not adequately compensate authors for their works, it explicitly made those rights inalienable and unwaivable when it granted

* Professor of Law at the University of Califormia at Berkeley School of Law and Director, Berkeley Center for Law \& Technology

** Professor from Practice at the UCLA School of Law; Of Counsel, Irell \& Manella LLP. Professor Nimmer served as counsel of record on behalf of Clare Milne, granddaughter of Winnie-thePooh author A.A. Milne, in a prominent termination-of-transfer copyright case, referenced in this Essay. See Milne v. Stephen Slesinger, Inc., 430 F.3d 1036 (9th Cir 2005). The termination-of-transfer aspect of that case is over.

This Essay is based upon an amicus brief submitted by the authors in support of the Supreme Court granting certiorari in Penguin Group (USA) Inc. v. Steinbeck, 537 F.3d 193 (2d Cir. 2008). The authors gratefully acknowledge the excellent research assistance of Adam Blankenheimer, Berkeley Law Class of 2010.

1. 17 U.S.C. $\S 304(c)(5)$ (2006) (emphasis added).

2. Penguin Group (USA) Inc. v. Steinbeck, 537 F.3d 193 (2d Cir. 2008), cert. denied, 129 S. Ct. 2383 (2009). 
the termination of transfer right under the current Act in 1976 and again via an amendment in $1998 .^{3}$

\section{A. 1909-The Right of RENEWAL AND ITS JUDGE-MADE ALIENABILITY IN FISHER}

Under the 1909 Act (which governed until January 1, 1978, the effective date of the current Act), authors enjoyed a twenty-eight year term of copyright protection and held the right to renew for an additional twenty-eight years. ${ }^{4}$ Congress intended this right to be "exclusive" to authors and their families so that they "could not be deprived of this right." Nevertheless, in 1943, the Supreme Court in Fred Fisher Music Co., Inc. v. M. Witmark \& Sons upheld an author's assignment of the right to renew copyright in his musical composition "When Irish Eyes are Smiling." Fisher refused to read the 1909 Act as imposing a restriction on the alienability of renewal interests because the statute did not explicitly provide one. ${ }^{7}$ As Justice White later observed, Congress's attempt to grant authors and their families a future copyright interest "was substantially thwarted by this Court's decision in Fred Fisher Music Co. v. M. Witmark \& Sons." 8

\section{B. 1976-CONGRESS OVERRIDES FISHER BY INTRODUCING THE TERMINATION of Transfer as AN INALIENABLE RIGHT OF RECAPTURE}

What the Fisher Court permitted under the 1909 Act, Congress explicitly forbade in the 1976 Act. In 1961, the Copyright Office submitted a comprehensive study of copyright law to Congress so that it might revise the 1909 Act. The report noted that the "reversionary feature of the present renewal system has largely failed

3. 17 U.S.C. $\$ \S 203(a)(5), 304(c)(5),(d)(1)(2006)$.

4. Pub. L. No. 349, §§ 23-24, 35 Stat. 1075, 1080-81 (1909).

5. H.R. REP. No. 60-2222, at 14 (1909)

6. Fred Fisher Music Co., Inc. v. M. Witmark \& Sons, 318 U.S. 643 (1943).

7. Id. at 655-56 (reasoning that if Congress had intended "statutory restraints upon the assignment by authors of their renewal rights, it is almost certain that such purpose would have been manifested"). The Fisher Court recognized, however, that the alienability of future copyright interests was a policy choice properly left for the legislature:

It is not for courts to judge whether the interests of authors clearly lie upon one side of this question rather than the other.... We do not have such assured knowledge about authorship ... as to justify us as judges in importing into Congressional legislation a denial to authors of the freedom to dispose of their property ....

Id. at 657. Nonetheless, when confronted with Congressional legislation that did impose such a denial in the interests of authors, the Second Circuit found a way around it. See infra Part III.A. As a result, it appears that Fisher's lesson remains unlearned even today.

8. Mills Music, Inc. v. Snyder, 469 U.S. 153, 185 (1985) (White, J., dissenting) (citation truncated). See also Siegel v. Warner Bros. Entm't, Inc., 542 F. Supp. 2d 1098, 1140 (C.D. Cal. 2008) (noting that the "re-valuation mechanism provided by the renewal term under the 1909 Act was largely frustrated by the Supreme Court's decision in Fred Fisher Music, 318 U.S. at 656-59, allowing authors to assign away at the outset all of their rights to both the initial and the renewal term"). 
to accomplish its primary purpose. It has also been the source of more confusion and litigation than any other provision in copyright law." "The study then commented that "the primary purpose of the reversionary interest would seem to require that the renewal interest be made unassignable in advance." 10 Congress included this suggestion in its first draft of the revised copyright bill.

The Draft Committee entertained several suggestions to update the author's reversionary right so as to remedy what was referred to as "the deficiency of the Supreme Court in Witmark v. Fisher." 11 These included: limiting all copyright assignments to twenty years with automatic reversion thereafter, permitting termination of assignments deemed to be unfair to authors and granting termination of assignments rights to authors who were only paid a lump sum upfront. The committee debates over reversion were quite spirited, and ultimately Congress chose to include sections granting authors the right to terminate an assignment of copyright. $^{12}$ Crucially, the proposed statute guaranteed authors a second opportunity to control copyright by ensuring that "termination [of the grant] may be effected notwithstanding any agreement to the contrary." 13 It would take almost twelve years and many more drafts before Congress enacted the Copyright Act of 1976 , but this language survived verbatim in order to "safeguard[] authors against unremunerative transfers." 14

\section{Termination of Copyright Grants Made Prior to the 1976 Act}

Notably, the 1976 Act provided that grants of copyright made under the new regime were to be terminable after thirty-five years from the date of the grant (the $\S$ 203 termination right), while grants of copyright made under the 1909 Act would be terminable fifty-six years after copyright was first obtained (the $\S 304(\mathrm{c})$ termination right). ${ }^{15}$ For Congress,

The arguments for granting a right of termination are even more persuasive under section 304 than they are under section 203; [extending the duration of existing copyrights by nineteen years] represents a completely new property right, and there

9. STAFF OF H. COMM. ON THE JUDiCIARY, 87TH CONG., COPYRIGHT LAW REvision: REPORT OF THE REGISTER OF COPYRIGHTS ON THE GENERAL REVISION OF THE U.S. COPYRIGHT LAW 53 (Comm. Print 1961).

10. Id. at 53-54.

11. STAFF OF H. COMM. ON THE JUdiciaRY, 88TH CONG., DisCUSSION AND COMMENTS ON THE REPORT OF THE REGISTER OF COPYRIGHTS ON THE GENERAL REVISION OF THE U.S. COPYRIGHT LAW,93 (Comm. Print 1963).

12. 1964 Revision Bill, H.R. 11947, 88th Cong. $\S \S 16(a)$, 22(c) (1964) (codified as 17 U.S.C. $\S \S$ 203(a), 304(c) (1976)).

13. Id. $\S \S 16(\mathrm{a})(1), 22(\mathrm{c})(1)$ (codified as 17 U.S.C. $\S \S 203(\mathrm{a})(5), 304(\mathrm{c})(5)(1976))$.

14. H.R. REP. No. 94-1476, at 124 (1976), as reprinted in 1976 U.S.C.C.A.N. 5659, 5740. See also Mills Music, Inc. v. Snyder, 469 U.S. 153, 172-73 (1985) (noting that Congress's intent to "relieve authors of the consequences of ill-advised and unremunerative grants that had been made before the author had a fair opportunity to appreciate the true value of his work product . . . is plainly defined in the legislative history and, indeed, is fairly inferable from the text of $\S 304$ itself').

15. 17 U.S.C. $\S \S 203(\mathrm{a}), 304$ (c) (2006). 
are strong reasons for giving the author, who is the fundamental beneficiary of copyright under the Constitution, an opportunity to share in it. ${ }^{16}$

Thus, Congress determined that the new property right of an extended copyright term should pass to the author and his statutory successors (his widow, children and grandchildren) rather than copyright assignees.

\section{Statutory Inheritance Scheme}

Moreover, the 1976 Act provided that if the author did not survive to exercise his termination right, the interest would be distributed to his family members as a statutory class. ${ }^{17}$ Congress specifically made this scheme inalienable: "Termination of the grant may be effected notwithstanding any agreement to the contrary ...."18 The author's family takes the interest despite any assignment or will of the author divesting them of copyright ownership. This provision shows Congress's intent to give the author's statutory successors, rather than the author's assignees or devisees, the benefits of copyright recapture-including the new property right of an extended term of protection.

\section{1998 - Congress EXTENDS Copyright Duration Again, Grants AUTHORS A SECOND INALIENABLE RIGHT OF RECAPTURE}

In 1998, the Sonny Bono Copyright Term Extension Act ("CTEA") extended copyright terms for another twenty years. ${ }^{19}$ Again wishing to bestow this additional term on authors and their families, Congress once again adopted the same termination device. ${ }^{20}$ Section 304 (d) allows the author's statutory successors to recapture copyrights that had been granted decades earlier, so long as they had not already exercised their termination rights. Again, the law granted authors and their successors a statutory termination right, allowing them to abrogate agreements by which the author had sold the extended term, "notwithstanding any agreement to the contrary.",21

However, the Second Circuit in Penguin Group (USA) Inc. v. Steinbeck undercut Congress's efforts to secure the added period of copyright protection for the author's surviving family. ${ }^{22}$ The following Part summarizes the case.

\section{PENGUIN V. STEINBECK}

In 1938, John Steinbeck assigned the publishing rights in his books to Viking Press in exchange for royalties. ${ }^{23}$ Penguin Group (USA) Inc. subsequently

\footnotetext{
16. H.R. REP. No. 94-1476, at 140, as reprinted in 1976 U.S.C.C.A.N. at 5756.

17. See 17 U.S.C. $\S \S 203(\mathrm{a})(2), 304$ (c)(2) (2006).

18. Id. $\S 304(\mathrm{c})(5)$ (emphasis added).

19. Pub. L. No. 105-298, 111 Stat. 2827 (1998).

20. See 17 U.S.C. $\S 304$ (d) (2006).

21. Id. $\S 304(\mathrm{c})(5)$, incorporated by reference in id. $\S 304(\mathrm{~d})(1)$.

22. 537 F.3d 193 (2d Cir. 2008), cert. denied, 129 S. Ct. 2383 (2009).
} 
assumed the contract from Viking and undertook its obligations to the author. ${ }^{24}$ Steinbeck died in 1968 , leaving his copyrights to his widow, Elaine Steinbeck. ${ }^{25}$ Steinbeck's sons from a previous marriage, Thomas Steinbeck and John Steinbeck IV, each received a sum of money but the author's will excluded them from ownership of the copyrights. ${ }^{26}$ When Congress granted the $\S 304$ (c) statutory termination right in 1978, Steinbeck's sons and his widow each had a one-half interest in the right to terminate. ${ }^{27}$

The widow and sons never formed the majority interest necessary to terminate the 1938 grant under $\S 304(\mathrm{c})$. Instead, Elaine Steinbeck, as owner of the copyrights to Steinbeck's books, entered into a new agreement with Penguin in 1994 to re-grant publishing rights to the works specified in the 1938 Agreement as well as some additional works. ${ }^{28}$ She received a larger guaranteed advance and an increased royalty rate, and the parties explicitly provided that the 1994 Agreement would end and supersede the 1938 Agreement. ${ }^{29}$ Neither Thomas nor John Steinbeck IV were parties to the 1994 Agreement.

After Elaine Steinbeck died in 2003, Thomas Steinbeck and Blake Smyle, John Steinbeck IV's surviving daughter, acquired the greater than half interest in Steinbeck's termination rights necessary to serve notice of termination upon Penguin. $^{30}$ In June 2004, Thomas and Blake, the author's only surviving child and grandchild ("Steinbeck Descendants"), served a notice to terminate the 1938 Agreement and recapture the copyrights from Penguin. ${ }^{31}$ Penguin replied that their notice of termination was invalid because the 1938 Agreement, having been superseded by the 1994 Agreement, was no longer terminable. ${ }^{32}$

The district court upheld the Steinbeck Descendants' termination notice on the grounds that, even if the 1994 Agreement superseded the 1938 Agreement, under $\$ 304(c)(5)$ it was "an agreement to the contrary" to the extent that it barred the Steinbeck Descendants from exercising their termination right. ${ }^{33}$ Judge Owen took the phrase "notwithstanding any agreement to the contrary" to mean "any contract the effect of which is in contravention of or which negates either of these [i.e., $\S$ 304(c) and $\S 304$ (d)] termination rights." 34 The court reasoned that to give the 1994 Agreement the effect of blocking Steinbeck's statutory successors from

23. Id. at 196.

24. Id.

25. $I d$.

26. Id

27. See 17 U.S.C. $\S 304(c)(2)(A)-(B)(2006)$.

28. Steinbeck, 537 F.3d at 196.

29. Id.

30. Although Elaine left her ownership interest in the copyrights to a variety of heirs (other than Thomas Steinbeck, John Steinbeck IV, and their children), her half-share of the termination right was not devisable or inheritable and hence expired upon her death. See 17 U.S.C. $\$ \S 304(c)(2)$, (d)(1) (2006).

31. Steinbeck, 537 F.3d at 197.

32. Id. at 199.

33. Steinbeck v. McIntosh \& Otis, Inc., 433 F. Supp. 2d 395, 402 (S.D.N.Y. 2006), rev'd and remanded, Steinbeck, 537 F.3d 193, cert. denied, 129 S. Ct. 2383 (2009); 17 U.S.C. $\S 304(\mathrm{c})(5)(2006)$.

34. Steinbeck, 433 F. Supp. 2d at 399 (citing 17 U.S.C. $§ 304(c)(5)$ ). 
exercising their termination right to the benefit of Elaine and her heirs would be "contrary to the very purpose of the termination statute." 35

On appeal, the Second Circuit reversed. The opinion validated the 1994 Agreement, which had the effect of superseding the 1938 Agreement. Therefore, there was no pre-1978 grant of copyright to terminate. ${ }^{36}$ To the argument that the Steinbeck Descendants could terminate the 1938 Agreement "notwithstanding any agreement to the contrary" under $\$ 304(\mathrm{c})(5)$, the Second Circuit did not read "agreement to the contrary" to mean any agreement that has the effect of eliminating a termination right, as the lower court had construed that phrase. ${ }^{37}$ The court concluded that neither the plain language nor legislative intent of the Copyright Act precluded authors and their statutory successors from losing the right to terminate a pre-1978 grant by renegotiating it. ${ }^{38}$ It held the statute satisfied by the circumstance that Elaine used her termination right as bargaining power to renegotiate the agreement with Penguin. ${ }^{39}$

Nor did the court consider the 1994 Agreement an "agreement to the contrary" because it barred exercise of the $\S 304$ (d) termination right, which Congress did not grant until $1998 .^{40}$ The court reasoned that, because $\S 304(\mathrm{~d})$ termination is available only if the rights-holder(s) has not already exercised $\S 304$ (c), the statute affords but one opportunity to use the termination right. ${ }^{41}$ Moreover, because Elaine used the $\S 304(\mathrm{c})$ termination right as a bargaining chip to renegotiate the original publishing agreement, she "exhausted the single opportunity provided by statute." 42 Thus, though the 1994 Agreement precluded the exercise of $\S 304(\mathrm{~d})$ termination rights, the court held that it did not violate the statute as an "agreement to the contrary." 43

\section{ANALYSIS}

The plain meaning of the phrase "[t]ermination of the grant may be effected notwithstanding agreement to the contrary" is that authors and their successors may terminate copyright assignments in spite of any contractual device that purports to divest them of the right; its plain legislative intent is to override Fisher by guaranteeing that authors and their successors have the opportunity to regain copyright. The U.S. Supreme Court has remarked that termination of transfer rights are "inalienable." 44 Yet the Steinbeck panel held that statutory successors"

35. Id. at 402 n. 23 .

36. Steinbeck, 537 F.3d at 202.

37. Id.

38. Id. at 203

39. Id. at 204 (" $[\mathrm{N}]$ othing in the statute suggests that an author or an author's statutory heirs are entitled to more than one opportunity, between them, to use termination rights to enhance their bargaining power or to exercise them.").

40. Id. at 202-03 ("We cannot see how the 1994 Agreement could be an "agreement to the contrary' solely because it had the effect of eliminating termination rights that did not yet exist.").

41. Id. at 202 (citing 17 U.S.C. $\S 304(\mathrm{~d})$ ).

42. Id. at 204 .

43. Id.

44. Stewart v. Abend, 495 U.S. 207, 230 (1990); see also N.Y. Times Co., Inc. v. Tasini, 533 
termination rights are alienated when the copyright owner renegotiates an existing grant. ${ }^{45}$ The decision harms the statutory successors of innumerable copyrights and undermines Congress's intention of shielding authors from the pressures of unequal bargaining power that had produced unremunerative transfers in the creative arts.

First, the Second Circuit's construction directly negates the plain language and intent of the statute. Congress made the termination rights inalienable because to do otherwise, as the assignable renewal interests of the 1909 Act demonstrated, would not sufficiently protect authors and their successors.

Second, the Steinbeck rule superimposes state contract law over the federal copyright statute to evaluate the legitimacy of federal copyright interests. Not only does this unpredictable standard invite litigation, it heralds further inconsistent law among the circuits.

Third, the decision will strip many authors' surviving children and grandchildren of their statutorily mandated copyright interests. Those children and grandchildren may now find their ability to terminate previous grants of copyright vanished through no fault of their own.

Critically, the case below implicates numerous valuable copyrights, as all copyrights that are not works-made-for-hire are subject to termination. ${ }^{46}$ Furthermore, the section governing the right to terminate post-1978 grants includes the identical provision that "[t]ermination of the grant may be effected notwithstanding any agreement to the contrary." 47 When such grants become terminable beginning in $2013,{ }^{48}$ courts are likely to look to the Steinbeck decision to determine whether the author's right to terminate is available. Authors and their successors can expect protracted courtroom battles when they attempt to enforce their statutorily mandated recapture rights.

\section{A. By Making Termination Rights Alienable, the Second Circuit RESURRECTS FISHER $V$. WITMARK AND ITS UNFORTUNATE EFFECTS ON AUTHORS AND STATUTORY SUCCESSORS}

The Second Circuit's decision has turned back the clock to the Fisher regime, under which publishers could contractually block authors and their families from exercising copyright reversion. Ironically, it did so by misinterpreting the very statutory provision that was intended to overrule the Fisher decision: "Termination... may be effected notwithstanding any agreement to the contrary . . ." 49 Indeed, the Second Circuit stated that it did not "read the phrase

\footnotetext{
U.S. 483, $496 \mathrm{n.3}$ (2001) (characterizing the statutory termination regime as creating an "inalienable authorial right to revoke a copyright transfer" under 17 U.S.C. $\$ 203(a)(5)$, the post-1978 provision coordinate to $\S 304(\mathrm{c})(5)$ for pre-1978 works).

45. Steinbeck, 537 F.3d. at 202-03.

46. 17 U.S.C. $\$ 304(c)$, (d) (2006).

47. Id. $\S 203(\mathrm{a})(5)$.

48. See David Nimmer \& Peter S. Menell, Sound Recordings, Works For Hire, and the Termination-of-Transfers Time Bomb, 49 J. COPYRIGHT SOC'Y 387 (2001).

49. 17 U.S.C. $\S 304(c)(5)(2006)$.
} 
'agreement to the contrary' so broadly that it would include any agreement that has the effect of eliminating a termination right." 50 That construction substitutes judicial discretion for the categorical rule that Congress legislated; in the process, it threatens to inflict the harms on authors and statutory successors that Congress intended its bright-line rule to avoid.

The Steinbeck panel reasoned that "nothing in the statute suggests that an author or an author's statutory heirs are entitled to more than one opportunity, between them, to use termination rights to enhance their bargaining power or to exercise them." G1 Granted, the statute does not provide more than one opportunity to terminate $^{52}$ But what it explicitly commands is that "[t]ermination ... may be effected notwithstanding any agreement to the contrary."53 In other words, absent an antecedent termination, the statute conveys an unambiguous right to terminate, regardless of what machinations have been undertaken to avoid that statutory termination right under state law (such as the "superseding" publishing agreement that Elaine and Penguin entered into in 1994). Accordingly, no occasion even arises for the statutory successors to realize any enhanced "bargaining power" apart from their statutory termination rights ${ }^{54}$-all other contracting parties should simply realize that, absent the successors' perfection of the various steps required to effectuate statutory termination, ${ }^{55}$ those successors retain the inalienable right to terminate in the future (until such time as the statutory termination window closes).

The Steinbeck panel also claimed " $[\mathrm{t}]$ here is ... no indication in the statutory text or the legislative history of the Copyright Act that elimination of a termination right through termination of a pre-1978 contractual grant was precluded or undesirable." ${ }^{, 56}$ But Congress explicated the so-called missing indication as tersely and plainly as it could: "the right [to terminate a transfer] cannot be waived in advance or contracted away." 57

50. Steinbeck, 537 F.3d at 202.

51. Id. at 204

52. Note that 17 U.S.C. $\S 304$ (d) accords a supplementary termination right, which is conditional on no previous termination having been effectuated under 17 U.S.C. $\S 304$ (c).

53. 17 U.S.C. $\$ 304(c)(5)$ (2006).

54. The Ninth Circuit in Milne v. Stephen Slesinger, Inc. made the similar mistake of equating the exercise of a statutory right with its contractual analogue. See 430 F.3d 1036, 1046 (9th Cir. 2005), cert. denied, 129 S. Ct. 2383 (2009) ("Congress sought to foster [the protection of authors] by permitting an author's heirs to use the increased bargaining power conferred by the imminent threat of statutory termination to enter into new, more advantageous grants.").

55. 17 U.S.C. $\$ 304(c)(3)$, (c)(4) (2006).

56. Steinbeck, 537 F.3d at 203. Cf. Milne, 430 F.3d at 1046-47 ("[N]o authority suggest[s] that Congress designed the statutory termination provisions to prevent the parties from agreeing to a simultaneous revocation and new grant of rights.").

57. H.R. REP. No. 94-1476, at 125 (1976), as reprinted in 1976 U.S.C.C.A.N. 5659, 5740; S. REP. No. 94-473, at 108 (1976). Although this language explicates $\S 203(a)$, it appears within the context of differentiating alienable renewal rights from inalienable termination rights in general, and for that reason is germane to $\S 304$ as well. The Second Circuit's oversight of this passage is all the more remarkable, given that elsewhere it employs the legislative history of $\S 203$ to construe $\S 304$. See Steinbeck, 537 F.3d at 203 (quoting H.R. REP. No. 94-1476, at 128). In that latter instance, however, the court cited material explicating $\S 203$ that was facially inapplicable to $\S 304$-and yet erroneously adduced it to interpret $\S 304$ 
Congress enacted a regime guaranteeing authors and their statutory successors a future copyright interest by voiding any agreement to the extent that it prevented that interest from vesting. Yet, to validate what it saw as fair bargaining activity between authors and publishers, the Steinbeck court carved out an exception for renegotiated agreements-even as the court recognized that "[t]he availability of termination rights under the Copyright Act is not dependent on the intent of the parties." 58 This decision transmogrifies the "availability of termination rights," which Congress intended to be unconditional, into a judicial inquiry dependent on an antecedent determination whether an existing copyright grant was renegotiated using the threat of termination as leverage. ${ }^{59}$ Congress wrote the statute as a categorical rule to overrule Fisher and to ensure that authors and their statutory successors enjoy the right to terminate a grant. Courts lack the power to rewrite that law into one embodying a wholly new balancing of interests, ${ }^{60}$ yet that is the consequence of the Second Circuit's decision.

\section{The Steinbeck Rule Enables Publishers To Strip Authors of Their Future Copyright Interests.}

Forgetting for a moment that the court somehow read the phrase "any agreement to the contrary" to mean "only some agreements to the contrary," the history of copyright law teaches that alienable reversionary interests stand to benefit publishers-and copyright lawyers ${ }^{61}$-at authors' expense. By granting inalienable termination rights to authors and their statutory successors, Congress sought to prevent the "confusion and litigation" spawned by the alienable renewal rights of the 1909 Act. The Second Circuit's decision reintroduces the uncertainty surrounding countless future copyright interests by holding that a renegotiation of a copyright grant is a substitute for its termination.

Just as Fisher sanctioned publishers' practice of securing renewal rights from authors and their families in order to preclude future copyright reversion, so now does Steinbeck encourage publishers to renegotiate copyright grants to prevent statutory heirs from later exercising termination. Publishers once again have an easy tool to block termination without having to confer adequate benefits on authors and their families. With a slight adjustment to the royalty rates or other contractual terms, an assignee will claim that a renegotiation superseded the original grant and thereby escape the prospect of termination. Copyright law has been here before; the scenario that the Second Circuit generates is identical to that which Congress tried to remedy in 1976.

58. Steinbeck, 537 F.3d at 201.

59. See infra Part III.B.

60. Eldred v. Ashcroft, 537 U.S. 186, 212 (2003) ("[I]t is generally for Congress, not the courts, to decide how best to pursue the Copyright Clause's objectives."); Stewart v. Abend, 495 U.S. 207, 230 (1990) ("[I]t is not our role to alter the delicate balance Congress has labored to achieve.").

61. One copyright practitioner recently referred to termination of transfers as "the gift that keeps on giving ... although potentially fraught with peril." Bill Gable, Taking it Back, L.A. LAWYER, June 2008 , at 34 . 


\section{B. The Steinbeck Rule IS UNPREdictable Because it LOOKS To State LaW Rather than Federal Statute to Determine the Validity of FEDERAL COPYRIGHT INTERESTS}

The Copyright Act permits authors and their successors to terminate a grant if they comply with statutory notice and timing requirements. The Second Circuit's decision imports the different legal regime of state law, such that federal termination becomes inoperative when publishers have engaged in machinations of re-granting, rescission, or novation. The availability of termination rights, which are federally granted property interests, now turns on whether there has been a superseding agreement under applicable state contract law. Indeed, the Steinbeck court looked to New York state law to determine whether Steinbeck's original grant to Penguin in 1938 had been superseded by Penguin's renegotiated contract with Steinbeck's widow in $1994 .{ }^{62}$ Such an inquiry guarantees further inconsistent law, encourages strategic forum shopping, and conflicts with clear federal policy pre-empting state laws that interfere with federal copyright law mandates and protections. $^{63}$

Nor do the circuits agree as to whether and in what circumstances a renegotiated grant extinguishes the right to terminate the original transfer. In contrast to Steinbeck, the Ninth Circuit recently held in Classic Media, Inc. v. Mewborn that a re-grant did not block an author's statutory successors from exercising termination because they did not use their termination rights as leverage during the renegotiations. ${ }^{64}$ The Ninth Circuit distinguished its prior decision in Milne $v$. Stephen Slesinger, Inc.--allowing a grantee to "revo[ke] and re-grant" a copyright license for the express purpose of blocking the author's family members from exercising their statutory termination rights ${ }^{65}-$ on the ground that the rights-holder there "had-and knew that he had-the right to vest copyright in himself at the very time he revoked the prior grants and leveraged his termination rights to secure the benefits of the copyrighted works for A.A. Milne's heirs." 66 None of these decisions follow the clear dictate of the federal statute that "[t]ermination of the grant may be effected notwithstanding any agreement to the contrary."67

How many more judicial roadblocks can the circuits place in front of authors and statutorily designated successors? After Milne, Steinbeck, and Mewborn, not only will courts have to apply state law to determine whether a copyright assignment has been superseded, they will have to investigate whether the relevant parties knew that they possessed termination interests at the time and whether they

62. 537 F.3d at $200-01$.

63. See 17 U.S.C. § 301(a) (2006); see also H.R. REP. No. 94-1476, at 129, as reprinted in 1976 U.S.C.C.A.N. at 5745 ("One of the fundamental purposes behind the copyright clause of the Constitution ... was to promote national uniformity and to avoid the practical difficulties of determining and enforcing an author's rights under the differing laws and in the separate courts of the various States.").

64. 532 F.3d 978, 989 (9th Cir. 2008)

65. 430 F.3d 1036, 1038 (9th Cir. 2005), cert. denied, 548 U.S. 904 (2006).

66. Mewborn, 532 F.3d at 989.

67. 17 U.S.C. $\$ 304(\mathrm{c})(5)$ (2006) (emphasis added). 
received just benefits from the renegotiated terms. Having courts measure the adequacy of such bargains is neither an appropriate nor predictable method of determining a property right that "may be exercised notwithstanding any agreement to the contrary."

\section{The STEINBECK RULE OVERRIDES CONGRESS'S INTENT to VEST COPYRIGHT INTERESTS IN STATUTORY SUCCESSORS}

Steinbeck invites crafty assignees to undermine the statute most readily in those situations where the statutory successors take the termination interest, but the author's will devises his copyright ownership interest elsewhere. Rather than bequeath their copyright royalties by will to their surviving family members, authors at times name in their will a favored charity, a mistress or a testamentary trust to act for the benefit of numerous interests. ${ }^{68}$ Notwithstanding those testamentary dispositions, Congress vested the right to terminate transfers automatically in the author's statutory successors (the surviving widow and children, and in the case of pre-deceased children, then the author's grandchildren). ${ }^{69}$ Aware that the copyright bar would exercise its ingenuity to devise stratagems to sidestep the termination interest, Congress further specified that the rights would not be subject to defeasement: "Termination of the grant may be effected notwithstanding any agreement to the contrary ...."70 Yet the Second Circuit's rule permits those rights to be eliminated when the inheritor of an author's copyright interest (the charity, mistress, trust, etc.) revisits the terms of a transfereven if the statutory successors are not party to the negotiations.

In fact, this scenario applies to the Steinbeck case. John Steinbeck devised the entirety of his copyrights to his widow, Elaine. ${ }^{71}$ Though Elaine only held a onehalf share of the right to terminate transfer of the copyrights, she received all of the benefits when she renegotiated the agreement with the publisher. ${ }^{72}$ The author's only surviving child and grandchild, who together held the other half share of the termination interest, received none. ${ }^{73}$ Allowing the author's devisee to unilaterally

68. Author William Saroyan may have preferred to leave his writings to his sister and a foundation as opposed to his own children. Saroyan v. William Saroyan Found., 675 F. Supp. 843, 84344 (S.D.N.Y. 1987), affd mem., 862 F.2d 304 (2d Cir. 1988). Composer Dave Dreyer left a portion of his earnings to his mistress. Larry Spier, Inc. v. Bourne Co., 953 F.2d 774, 776 (2d Cir. 1992). A.A. Milne left his interests in Winnie-the-Pooh not directly to his widow and surviving son, Christopher Robin Milne, but instead to a testamentary trust created for the benefit of various charities along with his family members. See Milne, 430 F.3d. at 1039.

69. 17 U.S.C. $\$ \S 203(a)(2), 304(c)(2)$, (d)(1) (2006).

70. Id. $\$ 304(\mathrm{c})(5)$.

71. Penguin Group (USA) Inc, v. Steinbeck, 537 F.3d 193, 196 (2d Cir. 2008), cert. denied, 129 S. Ct. 2383 (2009).

72. Id. The statute requires a majority share to exercise termination. 17 U.S.C. $\S 304(\mathrm{c})(1)$ (2006). Therefore, Elaine would have been unable to exercise termination on her own, even though the Second Circuit concluded that she "exhausted the single opportunity [for termination] provided by statute." Steinbeck, 537 F.3d at 204.

73. Steinbeck, 537 F.3d at 196. 
disinherit some (and, under other circumstances, all) members of the statutory class violates the statute.

Moreover, the rule of law adopted by the Steinbeck court encourages publishers to escape the possibility of termination by heading straight to the bargaining table with the author's testamentary devisee, regardless of whether he or she happens to be one of the statutory successors. The result is nothing other than a windfall to the testamentary devisee and publisher alike. Sometimes the lucky heir named in the will may turn out to be a surviving spouse locking out hostile children from the author's former marriage; in other instances, publishers may tender compensation to some of the author's progeny in order to induce them to give up their advance termination right, to the prejudice of other children or grandchildren; sometimes the device may be labeled "revocation and re-grant" (as it was in Milne); at other times, it will purport to "cancel and supersede the previous agreements" (as in Steinbeck); sometimes the new grant will occur when termination itself could already proceed under the statute, at other times prior to the termination window opening.

Steinbeck allows all these variations and more. Not one of them produces the result that Congress intended. The bedrock rule that should apply across the board is the one that Judge Owen articulated in the district court, before being reversed by the Second Circuit:

To protect this right and prevent creators or statutory heirs from contracting away, for whatever reason, this absolute right to "recapture" for the years of extended protection any pre-1978 copyright grant, the statute declares void any contract the effect of which is in contravention of or which negates either of these termination rights. ${ }^{74}$

\section{CONCLUSION}

The Second Circuit's decision in Steinbeck undermines the provision of the Copyright Act that guarantees the right of reversion to authors and their statutorily mandated successors. In so doing, it disrupts the overall statutory scheme, blocks authors' successors from realizing their statutory interests, and casts a pall of confusion over the ownership of many valuable copyrights. Congress could not have more clearly manifested its intent that authors and their families should enjoy an inalienable right to terminate transfer, and the Second Circuit could not have more patently violated it. The Steinbeck decision undercuts the integrity and clarity of Congress's language, and unmoors the statutory termination of transfer

74. Steinbeck v. McIntosh \& Otis, Inc., 433 F. Supp. 2d 395, 399 (S.D.N.Y. 2006), rev'd and remanded, Steinbeck, 537 F.3d 193, cert. denied, 129 S. Ct. 2383 (2009). "This statutory prohibition is intended to be broadly applied to invalidate such unlawful contracts and liberally protect termination rights. Indeed, copyright termination abrogates freedom of contract in two ways: it allows for the invalidation of the original contractual transfer, and it abrogates subsequent attempts to contract around the termination right it creates." Id. at 399 n. 10 (citations omitted). "Any interpretation of the 1994 Agreement having the effect of disinheriting the statutory heirs to the termination interest . . in favor of Elaine's heirs [the children of the surviving widow, not themselves related to the deceased author] must be set aside as contrary to the very purpose of the termination statute, which protects children and grandchildren, and not just widows." $/ d$. at 402 n.23. 
mechanism from its designated purpose of fairly protecting authors from overreaching and securing the interests of statutorily designated successors. 
